\title{
Tecendo saberes e práticas no aprender docente do campo: olhares, diálogos e interações do Pibid Diversidade
}

\author{
SILVA, Maria do Socorro ${ }^{1}$
}

\section{Resumo}

Este artigo tem como finalidade relatar e refletir sobre a vivencia do Pibid Diversidade Tecendo saberes e práticas no aprender docente do campo: olhares, diálogos e interações do curso de Licenciatura em Educação do Campo do Centro de Desenvolvimento Sustentável do Semiárido/UFCG, que se desenvolveu de março de 2014 a março de 2018, colocou-se como uma iniciativa afirmativa e na perspectiva do fortalecimento da iniciação a docência dos/as Licenciandos/as em Educação do Campo, numa perspectiva de dialogo entre o ensino, a pesquisa e a extensão nas Escolas de Educação Básica do Campo do Cariri Paraibano, tendo como eixo estruturante a docência multidisciplinar no processo formativo, o contexto do semiárido e o diálogo interinstitucional entre Universidade, Escolas e Secretarias de Educação. Refletir sobre a vivência do Pibid Diversidade leva necessariamente a discutir sobre a Licenciatura em Educação do Campo, e como este programa potencializou as concepções e estratégias deste Curso na UFCG, inclusive numa perspectiva de construção de comunidades de aprendizagem que envolvesse professores/as das escolas e formadores/as da Universidade, para propiciar uma iniciação a docência processual, sistemática e contextualizada na realidade dos sujeitos sociais a quem se destina o profissional da Educação do Campo.

Pibid Diversidade. Iniciação a Docência. Licenciatura em Educação do Campo.

Weaving knowledge and practices about teacher learning on countrified: perspectives, dialogues and interactions of the Pibid Diversidade

\begin{abstract}
This article aims to report and reflect on the Pibid Diversidade (Institutional Scholarship Initiative Program for Diversity) experience weaving knowledge and practices about teacher learning on countrified: perspectives, dialogues and interactions of the Countrified Education Undergraduate Course from the Center for Sustainable Development of the Semiarid/UFCG, which happened from March 2014 to March 2018, was put forward as an affirmative initiative and with a perspective to strengthening the teaching Licensors initiation in Countrified Education, in a perspective of dialogue between teaching, research and extension in the Basic Countrified Education Schools of the 'Cariri Paraibano' (region located in the south of the Brazilian State Paraíba), having as its structuring axis the multidisciplinary teaching in the formative process, the brazilian semi-arid region context and the interinstitutional dialogue between University, Schools and Education Secretariats. Reflecting on the experience of Pibid Diversidade necessarily leads to a discussion about the Degree in Countrified Education, and how this program potentiated the conceptions and strategies of this Course in the UFCG,
\end{abstract}

\footnotetext{
${ }^{1}$ Doutora em Educação pela UFPE. Professora da UFCG/CDSA na Unidade Acadêmica de Educação do Campo. Coordenadora Institucional do Pibid Diversidade Educação do Campo UFCG de 2014 a 2018. Atualmente coordena o Núcleo de Estudos e Pesquisa em Educação do Campo, Formação de Professores/as e Prática Pedagógica.
} 
including on a learning building communities perspective that involved teachers from schools and University trainers, to provide an introduction to procedural, systematic and contextualized teaching in the social subjects reality to which the Countrified Education professional is intended.

Pibid Diversidade. Teaching Initiation. Countrified Education Degree.

\section{Introdução}

O Curso de Licenciatura em Educação do Campo, doravante denominado Lecampo, é curso regular da UFCG, criado em 2009, localizado no campus da UFCG, no município de Sumé, no território do Cariri Paraibano. A construção de uma licenciatura que tem como base a docência multidisciplinar, por área de conhecimento para atuação nos anos finais do ensino fundamental e no ensino médio do campo, já representa por si só um desafio para a academia, isto se acentua quando esta formação traz consigo a organização do trabalho pedagógico em alternância de tempos e espaços formativos.

A proposta da Lecampo no CDSA se inseriu no esforço nacional que integrou os Movimentos Sociais e Sindicais do Campo, Fóruns e Comitês Estaduais, Municipais e Territoriais da Educação do Campo, na defesa de uma Política Nacional de Educação do Campo, na perspectiva de estimular as Universidades Públicas na criação de cursos regulares de Licenciatura em Educação do Campo, para a docência multidisciplinar nos anos finais do Ensino Fundamental e no Ensino Médio, com a finalidade de formar professores (as) aptos a fazer a gestão de processos educativos escolares e não escolares no campo brasileiro e a desenvolver ações educativas que visem à formação de sujeitos autônomos e criativos, capazes de produzir soluções para questões inerentes à sua realidade, vinculadas à construção de um projeto de desenvolvimento sustentável para o país (PPP LECAMPO, 2009).

Para Pimenta, (2006), A fase de formação inicial docente é muito importante no processo da construção da identidade profissional e na constituição da carreira de professor, é um período marcado por muitas experiências, questionamentos, aprendizagens. Portanto, de construção da identidade docente e do repertório de conhecimentos para a iniciação na docência. 
Por isto, que a Licenciatura da Educação do Campo tem como eixo da formação a docência². A Docência, nessa concepção, inscreve-se no interior de um processo formativo e não numa visão reducionista de um conjunto de métodos e técnicas neutros, descolados de uma dada realidade histórica. Em seu sentido estrito, a docência é compreendida como processo baseado em princípios teórico metodológicos, ato intencional, vinculado às especificidades dos processos de ensino-aprendizagem. Numa compreensão de que a iniciação à docência se constitui num entrelaçamento de práxis entre a Escola Básica e a Universidade como espaços formadores e de aproximação dos estudantes do curso com os sujeitos e com o espaço de desenvolvimento de sua profissão.

A docência nesta proposta foi compreendida numa perspectiva plural que articula espaços educativos diversos e funções diversas nas práticas educativas, ao articular ao longo da formação a docência com a gestão escolar, portanto, como dimensões inseparáveis da formação e do exercício do profissional docente do campo. E principalmente um docente que tenha um pertencimento com o campo.

Os movimentos sociais contribuem para a confirmação de uma concepção de educação que incorpore essa pluralidade de dimensões e funções formadoras. Defendem uma relação estreita entre a função educativa, diretiva e organizativa no perfil de educador; dão ênfase às didáticas não apenas escolares, de ensino, mas às estratégias e didáticas para a direção e consolidação da Reforma Agrária e dos movimentos (ARROYO, 2012, p. 365).

Esta dimensão da docência apoiasse no compromisso ético do professor/a com aqueles a quem ensina: recuperam-se assim, as dimensões epistêmicas, políticas e éticas da ação docente.

Em 2013, a CAPES, lançou um edital contemplando o atendimento de escolas com especificidades distintas tais como: as escolas do campo e escolas indígenas, este Edital oㅜ 066/2013 PIBID-DIVERSIDADE contemplou 3.000 bolsas direcionadas a Licenciandos/as de cursos de Licenciatura Intercultural Indígena e Educação do Campo.

Essa perspectiva de vinculação com a proposta pedagógica da Lecampo orientou a elaboração do objetivo geral do Pibid Diversidade, que consistiu em proporcionar aos futuros professores (as) a inserção na Escola Pública para

\footnotetext{
${ }^{2}$ Temática pauta de discussões de estudiosos em eventos promovidos, por exemplo, pela ANFOPE - Associação Nacional pela Formação dos Profissionais da Educação, desde a década de 1980.
} 
participação na organização do trabalho pedagógico das escolas; o aprendizado e acolhimento da diversidade existente; o aprimoramento das práticas investigativas a partir da reflexão sobre a prática pedagógica; o uso de tecnologias da informação e da comunicação; de metodologias e materiais de apoio inovadores; do desenvolvimento de hábitos de colaboração e de trabalho em equipe; da interação da escola com a comunidade de forma a estimular 0 desenvolvimento do espírito cientifico nos licenciandos/as, nos educandos/as e professores/as das escolas públicas envolvidas neste Projeto; e como, objetivos específicos:

$\checkmark$ Contribuir para o processo de formação inicial do magistério elevando a qualidade da formação inicial de professores no Curso de Licenciatura em Educação do Campo e promovendo a integração entre educação superior e educação básica;

$\checkmark$ Estimular junto aos integrantes do Pibid Diversidade olhares investigativos que oportunizem a apreensão dos saberes construídos na prática docente, possibilitando diálogos entre a formação dos/as professores/as e o fazer pedagógico em construção nas Escolas Básicas do Campo;

$\checkmark$ Propiciar um processo formativo que leve em consideração a interculturalidade do território, o trabalho e a cultura campesina, a agroecologia e suas implicações no trabalho pedagógico;

$\checkmark$ Propiciar uma prática de ensino e aprendizagem inclusiva que interaja com a realidade e a cultura local, ampliando assim o conhecimento estético e artístico-musical dos nossos licenciandos e dos estudantes e professores do Ensino Fundamental do Cariri Paraibano;

$\checkmark$ Contribuir para o fortalecimento da educação do campo por meio da reflexão crítica das atividades didático-pedagógicas, produzidas nos ambientes escolares e relacionadas às particularidades de cada comunidade ou região;

$\checkmark$ Contribuir para a ampliação do acesso dos/as estudantes da escola pública à universidade, com a participação em eventos de extensão e pesquisa da UFCG, estimulando sua opção por cursos ofertados no CDSA;

$\checkmark$ Contribuir para aumento da demanda pela Licenciatura em Educação do Campo, como também para diminuição da evasão no curso;

$\checkmark$ Contribuir para melhoria do fluxo escolar, da aprendizagem e contextualização do currículo das escolas do campo da região.

O relato desta experiência que adotou um procedimento descritivo-analítico teve por objetivo registrar, discutir $e$ analisar as especificidades e possibilidades do Pibid Diversidade junto a Licenciatura e as escolas da 
educação básica do território nos levaram a indagar sobre: Qual a contribuição deste programa para os sujeitos envolvidos? Como a organização do programa potencializou as concepções e estratégias adotadas na Licenciatura em Educação do Campo no que se refere à formação e a atuação docente do campo?

\section{Situando o Contexto}

O Pibid Diversidade por sua vinculação direta com a Licenciatura em Educação do Campo teve como ponto de partida de sua estruturação a realidade ambiental, social, cultural e educacional do território do Cariri Paraibano, no qual se situa as escolas de atuação do programa. O Cariri paraibano subdivide-se em oriental e ocidental e apresenta as seguintes configurações:

\section{Mapa 1 - Municípios do Cariri Ocidental e Oriental}

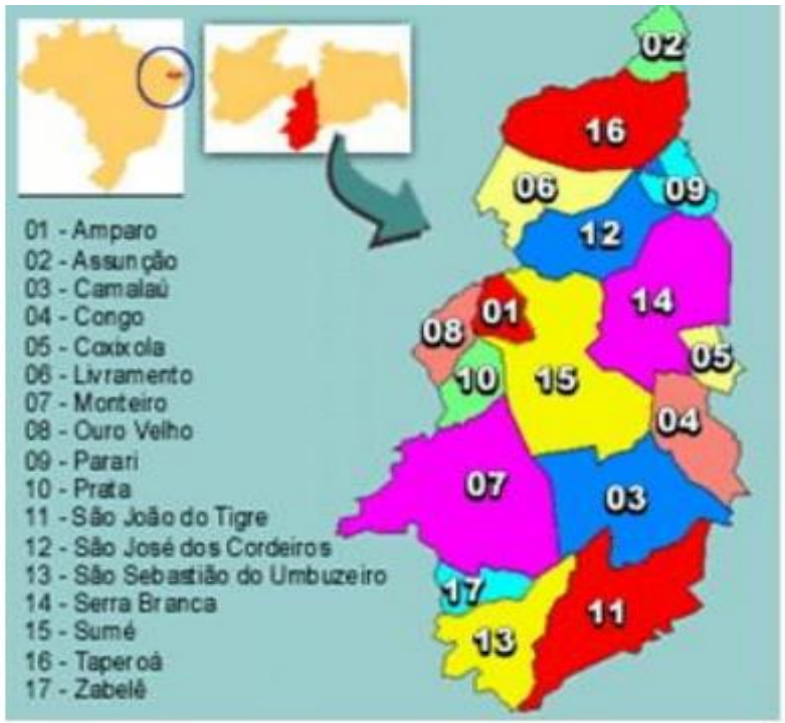

CARIRI OCIDENTAL

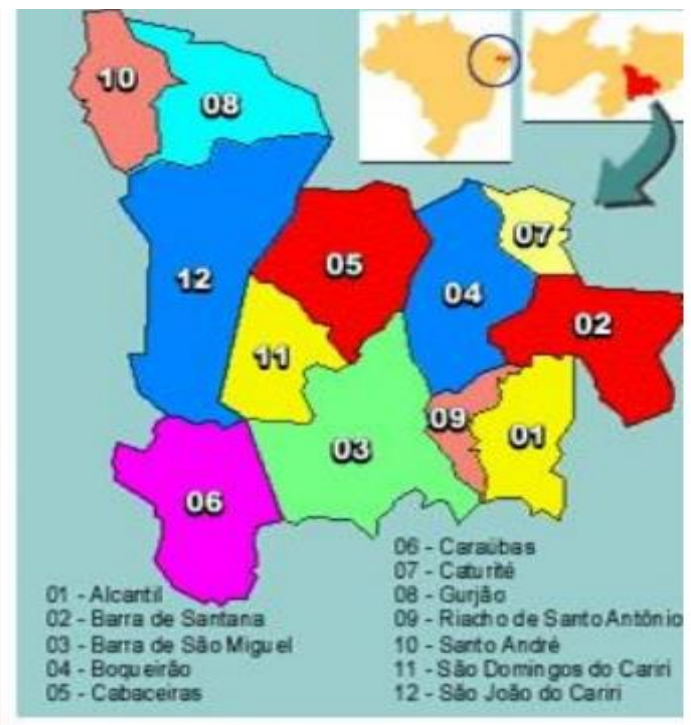

CARIRI ORIENTAL

Fonte: IBGE.

Embora o Semiárido brasileiro seja um dos espaços semiáridos mais povoados do mundo, a expansão urbana se faz de forma desordenada, além do que os municípios apresentam infraestrutura social precária. No caso do Cariri paraibano, a maioria dos municípios tem menos de 50 mil habitantes, densidade demográfica inferior a 20 habitantes por $\mathrm{km}^{2}$, e uma economia eminentemente agropecuária, evidenciando a marca da ruralidade neste território. 
O movimento que hoje se procede no pensar, agir e conduzir os debates acerca de um modelo de desenvolvimento apropriado para o Semiárido aponta para a falência da lógica de combate à seca e a emergência da lógica da convivência com o Semiárido, caminhando, portanto, para a emergência de uma lógica ambiental-sistêmica.

Tal perspectiva coloca desafios para a Universidade enquanto espaço de pesquisa e produção do conhecimento, consequentemente, como formadora de profissionais e educadores (as) que possam contribuir para a construção de referenciais e práticas sustentáveis para a região.

A realidade educacional do Cariri requisita uma contribuição da Universidade na perspectiva de ensino, pesquisa e extensão visando superar os índices de desenvolvimento atualmente apresentados. Como exemplos, desta realidade a ser superada, podemos citar: $67,13 \%$ das pessoas com mais de 15 anos não têm nenhuma instrução ou possuem apenas o ensino fundamental incompleto, realidade que caracteriza nada menos do que $74 \%$ da população de 25 anos ou mais e 44,77\% dos jovens entre 15 e 24 anos.

No território do Cariri Ocidental temos 100 escolas localizadas nas comunidades rurais, destas apenas 02 (duas) oferecem ensino médio e 15 (quinze) tem oferta dos anos finais do ensino fundamental, etapas da educação básica de atuação do Licenciado em Educação do Campo. Essa foi uma preocupação ao longo do Programa, como articular estas escolas em diferentes ações desenvolvidas pela licenciatura, inclusive, selecionando dentre estas o campo de atuação da iniciação à docência.

\section{Contextualizando a ação}

O Pibid Diversidade constituído por três subprojetos, desenvolvidos em seis escolas, situadas nos seguintes municípios: Sumé (15), Amparo (01), Monteiro (07) e São João do Cariri (localizado no Cariri Oriental -12). Assim, o diálogo interdisciplinar e intercultural, a organização de coletivos de trabalho e uma prática pedagógica por área de conhecimentos, foram à base para elaboração dos três subprojetos:

$\checkmark$ Educação do Campo - Linguagens e Códigos (ênfase na leitura, escrita, literatura, cultura corporal e educação musical);

$\checkmark$ Educação do Campo - Humanas e Sociais (com ênfase na história, geografia, sociologia e filosofia) e;

$\checkmark$ Educação do Campo - Ciências da Natureza e matemática (ênfase em Ciências Biológicas, Física e na Matemática).

Durante este período nos inserimos de forma sistemática e permanente em 06 (seis) escolas da rede pública, sendo 03 (três) municipais com oferta do ensino fundamental e 03 estaduais com oferta do ensino fundamental e médio. 
Além disto, desenvolvemos atividades eventuais outras escolas públicas, com atividades de oficinas, palestras, participação em eventos na universidade.

Para a escolha das escolas consideramos aquelas que se autodenominam Escolas do Campo, e as que mesmo localizadas na sede do município, possuem um número significativo de estudantes oriundos das comunidades rurais. Consideramos assim, o que esta previsto no Decreto Presidencial $n^{-}$7.352, de 04 de novembro de 2010, ao conceituar em seu inciso II, a Escola do Campo.

II - escola do campo: aquela situada em área rural, conforme definida pela Fundação Instituto Brasileiro de Geografia e Estatística - IBGE, ou aquela situada em área urbana, desde que atenda predominantemente a populações do campo.

Esta definição das Escolas do Campo foi discutida sempre ao longo do processo com o coletivo de professores/as das escolas, numa perspectiva de, sensibilização do coletivo para construir um Projeto Político Pedagógico contextualizado a realidade do semiárido. O Gráfico 1 apresenta a área de atuação do Pibid Diversidade UFCG.

\section{Gráfico 1 - Área de atuação do Pibid Diversidade UFCG}

\begin{tabular}{|c|c|c|c|}
\hline Escola & $\begin{array}{c}\text { Município } \\
\text { Comunidade }\end{array}$ & Subprojeto & Etapa \\
\hline $\begin{array}{c}\text { Escola Jornalista José } \\
\text { Leal Ramos }\end{array}$ & $\begin{array}{l}\text { São João do } \\
\text { Cariri - sede do } \\
\text { município }\end{array}$ & $\begin{array}{l}\text { Linguagens e Códigos } \\
\text { Ciências Humanas e } \\
\text { Sociais }\end{array}$ & $\begin{array}{l}\text { Anos finais do } \\
\text { Ensino fundamental } \\
\text { e Ensino Médio }\end{array}$ \\
\hline $\begin{array}{c}\text { Escola do Campo } \\
\text { Bento Tenório de } \\
\text { Sousa }\end{array}$ & $\begin{array}{c}\text { Monteiro - } \\
\text { Assentamento } \\
\text { Santa Catarina }\end{array}$ & Linguagens e Códigos & Ensino Médio \\
\hline $\begin{array}{l}\text { Escola Agrotécnica } \\
\text { Evaldo Gonçalves }\end{array}$ & $\begin{array}{l}\text { Sumé - sede } \\
\text { do município }\end{array}$ & $\begin{array}{c}\text { Ciências da Natureza e } \\
\text { da Matemática }\end{array}$ & $\begin{array}{c}\text { Anos finais do } \\
\text { ensino fundamental }\end{array}$ \\
\hline $\begin{array}{c}\text { Escola do Jose } \\
\text { Bonifácio de Andrade }\end{array}$ & $\begin{array}{c}\text { Sumé - Distrito } \\
\text { do Pio X }\end{array}$ & $\begin{array}{c}\text { Ciências da Natureza e } \\
\text { da Matemática } \\
\text { Linguagens e Códigos } \\
\text { Ciências Humanas e } \\
\text { Sociais }\end{array}$ & $\begin{array}{l}\text { Anos iniciais e anos } \\
\text { finais do ensino } \\
\text { fundamental }\end{array}$ \\
\hline $\begin{array}{c}\text { Escola Idelfonso } \\
\text { Anselmo }\end{array}$ & $\begin{array}{l}\text { Amparo - sede } \\
\text { do município }\end{array}$ & $\begin{array}{c}\text { Ciências Humanas e } \\
\text { Sociais }\end{array}$ & $\begin{array}{c}\text { Anos finais do } \\
\text { Ensino Fundamental }\end{array}$ \\
\hline $\begin{array}{c}\text { Escola Presidente } \\
\text { Vargas }\end{array}$ & $\begin{array}{l}\text { Sumé - sede } \\
\text { do município }\end{array}$ & Linguagens e Códigos & $\begin{array}{c}\text { Anos finais do } \\
\text { Ensino Fundamental }\end{array}$ \\
\hline
\end{tabular}

Fonte: organizado pela autora.

Ao longo dos 04 anos do Pibid Diversidade tivemos o envolvimento direto de cerca 1.200 estudantes da educação básica e de 50 professores/as que participaram de diferentes atividades desenvolvidas nas escolas. Destes, 
16 atuaram diretamente como professores/as supervisores/as de bolsistas de iniciação à docência.

Do ponto de vista da UFCG/CDSA, tivemos ao longo dos 04 anos o envolvimento direto de 04 docentes da área de Linguagens e Códigos, 03 docentes da área de Ciências da Natureza e da Matemática e de 06 docentes da área de Ciências Humanas e Sociais, mais 01 coordenadora institucional do Programa o que representa o envolvimento de 14 docentes.

No que se refere aos bolsistas de iniciação à docência, estudantes vinculados a Licenciatura em Educação do Campo, dos 218 vinculados ao curso, durante a vigência do Programa, 181 deles foram bolsistas Pibid em diferentes momentos do seu itinerário formativo. Isso também evidencia a importância deste Programa, não apenas pela sua dimensão política e pedagógica, mais também, pela existência de uma bolsa possibilitar que muitos estudantes permanecessem e concluíssem sua formação inicial.

Os subprojetos desde o inicio assumiram uma postura de discussão e formulação coletiva com os diferentes sujeitos envolvidos na ação, o que nos possibilitou, inclusive, nos períodos de ausência de recursos de custeio, desenvolve as atividades nas escolas com suporte destas parcerias.

O lócus da formação inicial do estudante é a universidade em estreita relação com as redes públicas de ensino. No Pibid Diversidade, o foco sempre se colocou nas redes públicas de ensino, em especial suas unidades escolares de educação básica, sendo seus professores/as considerados como coformadores dos bolsistas de iniciação à docência - licenciandos/as em formação. Isso exigiu uma relação mais orgânica entre a universidade, a Lecampo, a gestão das escolas e em alguns municípios uma relação de parceria com as Secretarias Municipais de Educação.

A mediação pedagógica contextualizada na vida, no trabalho e na cultura dos Povos do Campo no Semiárido, foi o que buscamos contemplar na formação dos/as Licenciandos/as em Educação do Campo, e no trabalho desenvolvido pelo PIBID DIVERSIDADE.

\section{Organização da ação}

Cada subprojeto possuía a sua coordenação de área que coordenava todas as ações e respondia por elas junto a coordenação institucional; os/as supervisores/as que são professores/as das escolas parceiras, e que orientavam os bolsistas no cotidiano da escola foram fundamentais no acompanhamento e monitoramento do trabalho e da parceria entre universidade e escola básica.

Os bolsistas estudantes da licenciatura eram vinculados ao projeto a partir da área de conhecimento que optam no curso, o que possibilitou a articulação entre teoria e prática nos tempos escola e comunidade, o estímulo 
para a pesquisa docente, e principalmente a reflexão na e para a iniciação a docência no campo nos espaços da sala de aula, quando podiam exemplificar as vivências nas escolas a partir de suas práticas no Pibid Diversidade.

Nos diferentes espaços de discussão, avaliação e planejamento os mesmos iam se articulando e integrando-se com atividades comuns que possibilitavam uma unidade institucional ao projeto. Esta articulação era fomentada por reuniões periódicas de todos os membros dos subprojetos com a coordenação institucional, e o planejamento conjunto de atividades a serem desenvolvidas para socialização da produção pedagógica e cientifica do trabalho.

A utilização de ferramentas da tecnologia da informação como site do projeto, redes sociais, Facebook do projeto, WhatsApp do colegiado dos coordenadores/as e supervisores/as possibilitaram a socialização e troca de experiências das ações realizadas por cada subprojeto e nas escolas, complementado pelas visitas de acompanhamento ao trabalho pelos coordenadores/as de área e institucional.

\section{Estratégias Pedagógicas Desenvolvidas pelo projeto}

Durante a execução do projeto de março de 2014 a março de 2018, as ações se desdobraram em diferentes estratégias pedagógicas, alguns permanentes durante todo o período, como: reuniões de planejamento e formação, docência compartilhada e plantão pedagógico, produção de material didático, realização de relatórios e participação em eventos de socialização do trabalho. Podemos enfatizar em cada ano algumas estratégias.

\subsection{Atividades nas escolas campo de atuação}

No primeiro ano do projeto diversas ações foram desenvolvidas: Vivência Escolar - finalidade - Inserir os alunos bolsistas no ambiente escolar, para compreender e se integrar no cotidiano da escola com diagnósticos, leitura de documentos das escolas, participação na dinâmica escolar, formação da equipe e planejamento do trabalho de forma continuada, acompanhamento às práticas pedagógicas desenvolvidas na escola, monitoramento e avaliação do trabalho, socialização do trabalho em eventos culminando com a realização do I Encontro do Pibid Diversidade da UFCG, que contou com a participação de professores, estudantes e gestores da Universidade e das Escolas de Educação Básica. 


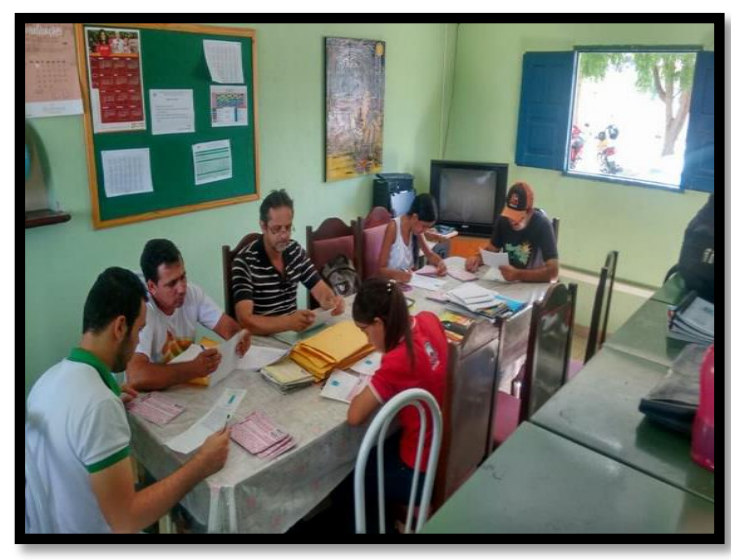

Foto 01 - Reunião de bolsistas e supervisor

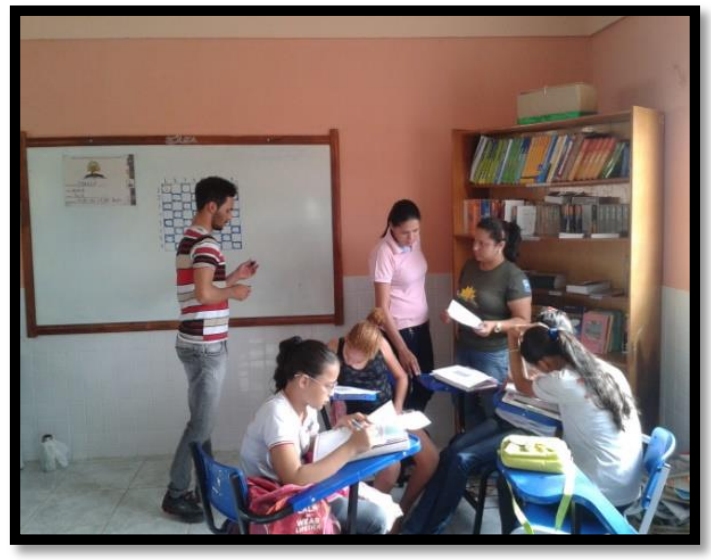

Foto 02 - Preparação para a OBMEP

No segundo ano do projeto é possível perceber uma gradativa evolução dos educandos/as das escolas conveniadas no desenvolver das atividades planejadas pelos bolsistas em parceria com os professores/as regentes. Com isso, é percebido que o projeto vem desenvolvendo sua função e contribuindo para uma releitura do processo pedagógico nessa teia que interliga tantos aprendizados, instituições sujeitos. Participação dos bolsistas na elaboração de projetos interdisciplinares focados em temáticas regionais condizentes com a realidade em que estão situados, produção de materiais didáticos para trabalho com os temas em sala de aula, Elaboração de materiais audiovisuais, promovendo a execução de aulas com o uso de vídeos, CDs e despertando o interesse pelo uso das mídias em sala de aula; revitalização das salas de leitura, de viveiro de mudas e constituição do clube de ciências e matemática, organização dos laboratórios das áreas de conhecimento na universidade, visitas de campo e intercambio entre as escolas.

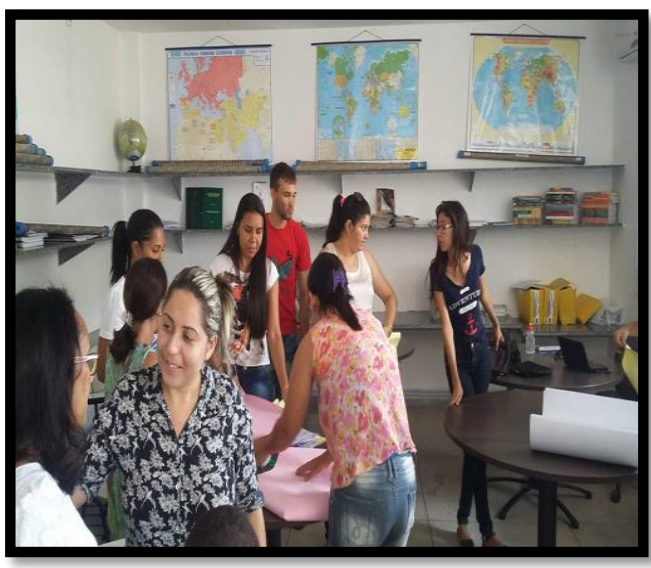

Foto 03 - Organização do Laboratório

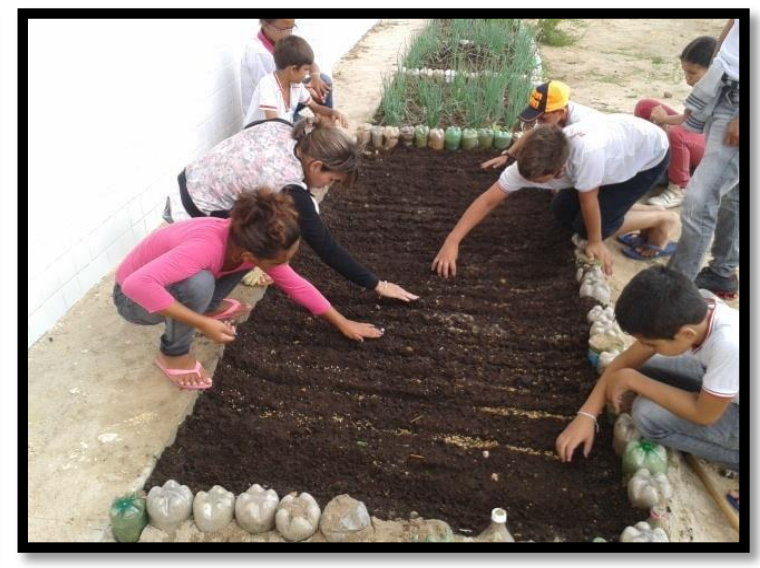

Foto 04 - Organização da horta na escola 


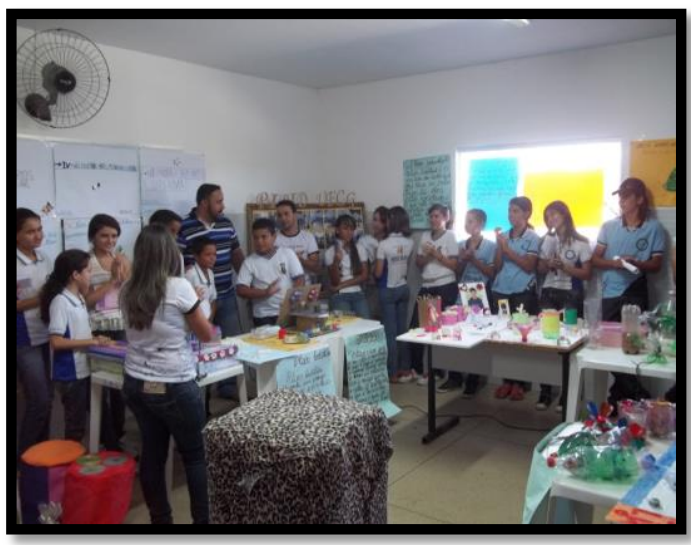

Foto 05 - Exposição de material didático

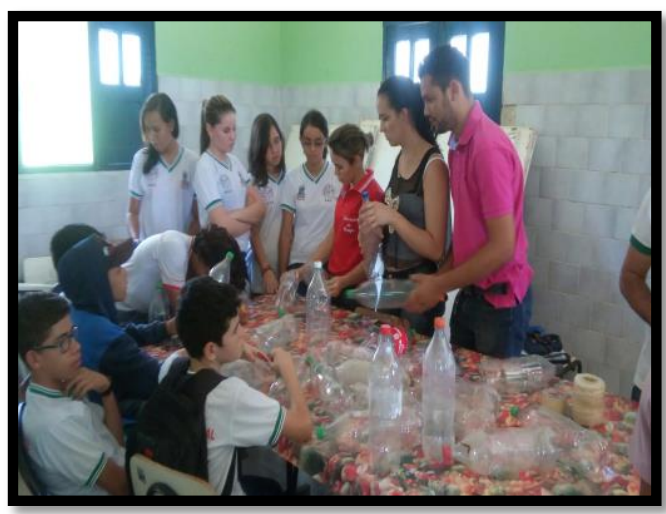

Foto 07 - Oficina de produção de material

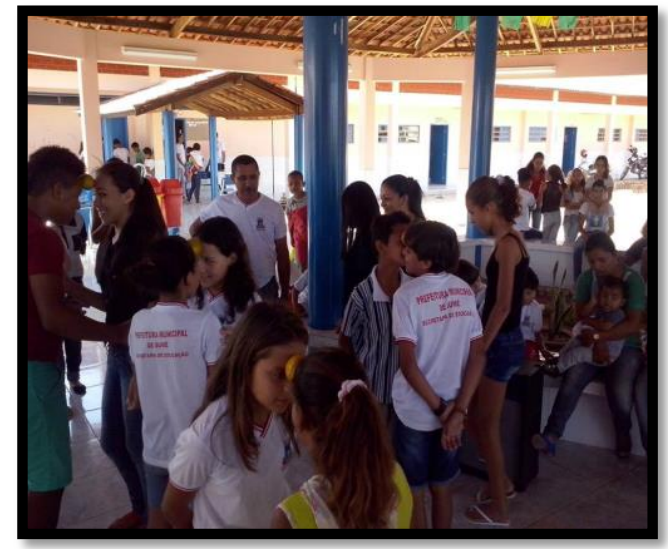

Foto 06 - Atividade lúdica na escola

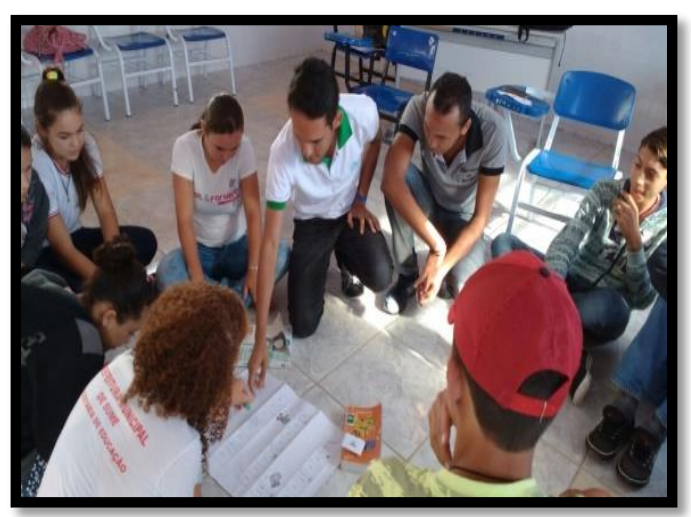

Foto 08 - Docência Compartilhada

No terceiro ano do projeto, além do fortalecimento das ações desenvolvidas nos dois anos anteriores, o projeto buscou focar numa maior articulação com a comunidade escolar interna e externa na escola, no desenvolvimento de atividades que envolvesse toda a comunidade, na participação de articulações sobre a discussão da formação de professores/as do campo no território, em atividades envolvendo multimídias, na produção de materiais didáticos e na participação em eventos acadêmicos.

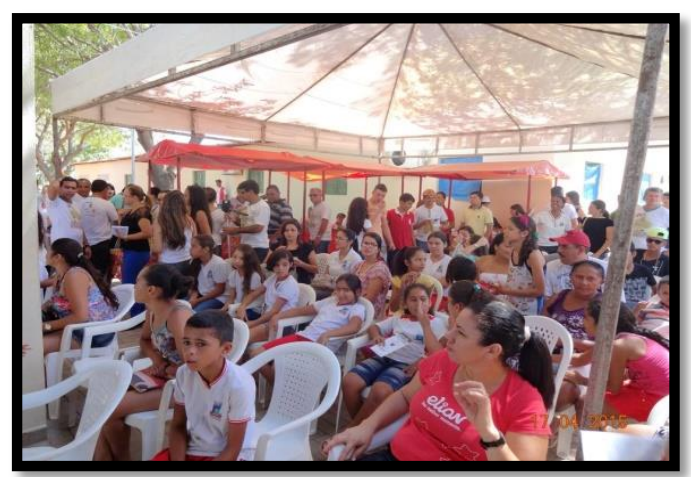

Foto 09 - Atividade com a comunidade

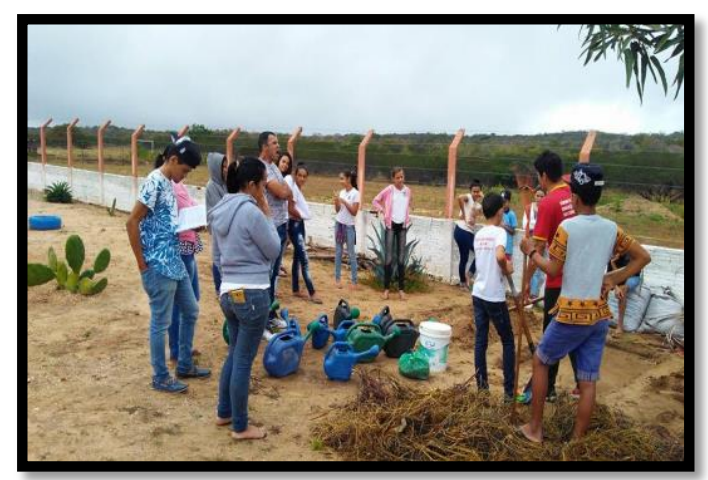

Foto 10 - Oficina de composto orgânico 


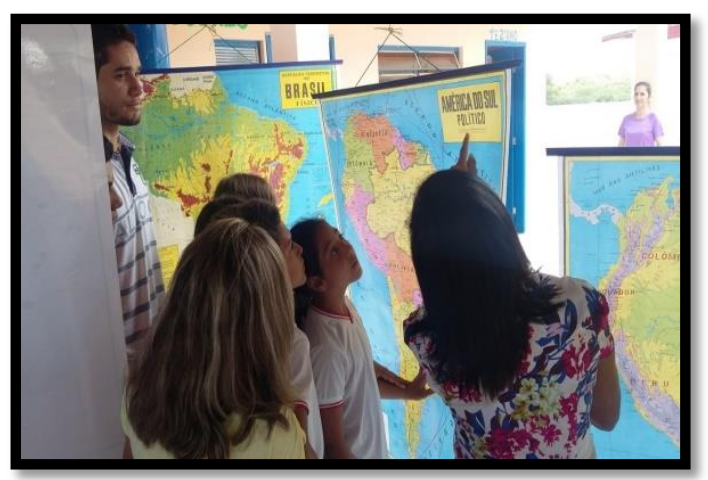

Foto 11 Exposição Itinerante de Mapas

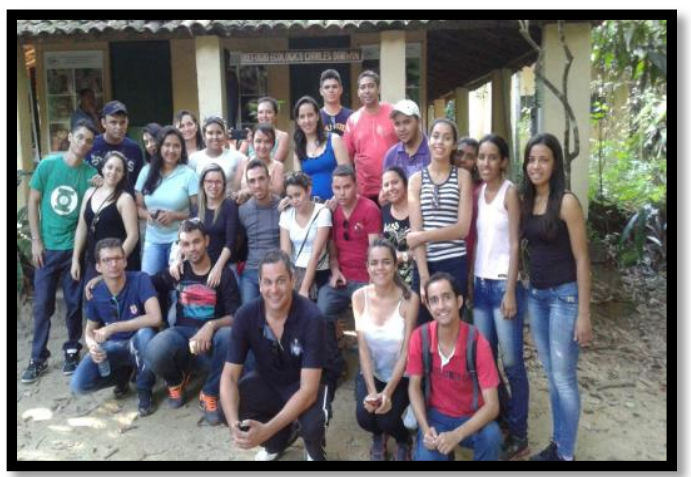

Foto 12 - Visita de estudo

No quarto ano do projeto, além do fortalecimento das ações desenvolvidas nos anos anteriores, podemos destacar: realização das feiras de ciências envolvendo toda a comunidade escolar e comunidade externa, construção de hortas nas escolas, áreas de jardinagem com plantas medicinais, realização dos jogos escolares, participação na Olimpíada da matemática, realização de festivais culturais, atividades integradas com o Pibic Ensino Médio, atuação na EJA fundamental na Jornalista José Leal e Pio X, realização de campanhas educativas como: prevenção da dengue, setembro amarelo prevenção ao suicídio na adolescência, participação nos eventos regionais do Pibid Diversidade.

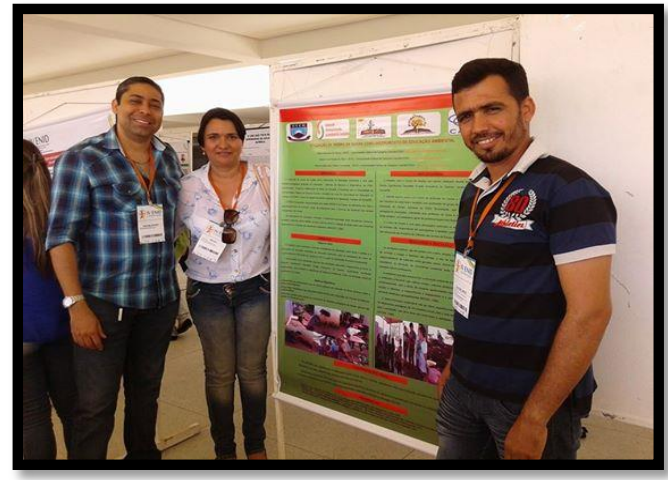

Foto 13- Apresentação de trabalho

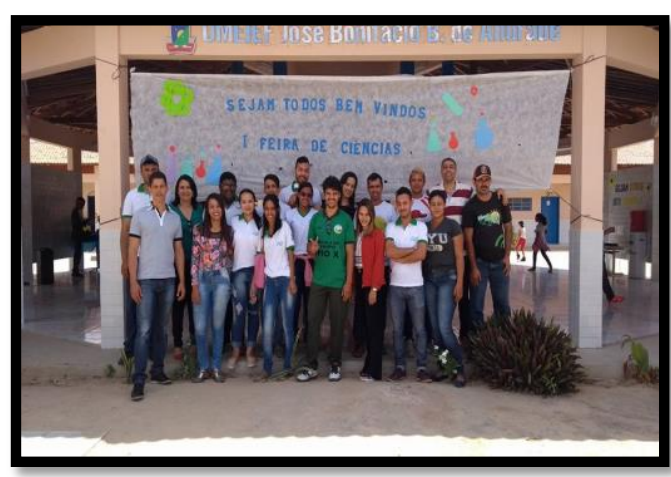

Foto 15 - Feira de Ciências

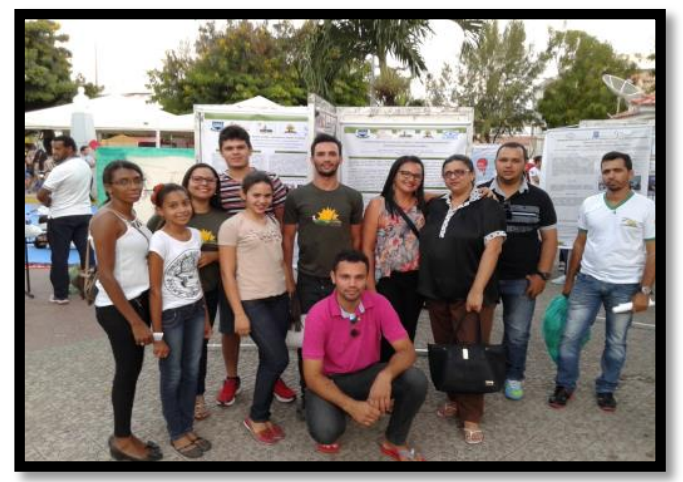

Foto 14 - Feira de Saberes na Praça

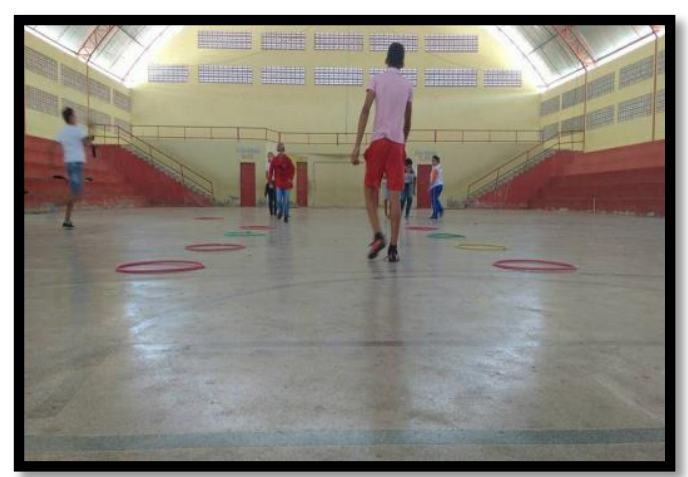

Foto 16 - Cultura Corporal nas escolas

Interritórios | Revista de Educação Universidade Federal de Pernambuco Caruaru, BRASIL | V.4 N.7 [2018] 
O contato semanal, as oficinas e o acompanhamento das aulas, desenvolvem entre as partes, um sentimento de confiança e respeito e esta situação facilita o desempenho tanto dos alunos, no questionamento ou na busca de respostas às suas dúvidas quanto dos acadêmicos nas eventuais apresentações de trabalhos e oficinas.

De fato, Pimenta (1997) destaca que a formação inicial de professoreslas baseada no desenvolvimento de um currículo formal com conteúdos, distanciada do contexto real da sala de aula, não captura a complexidade da prática docente.
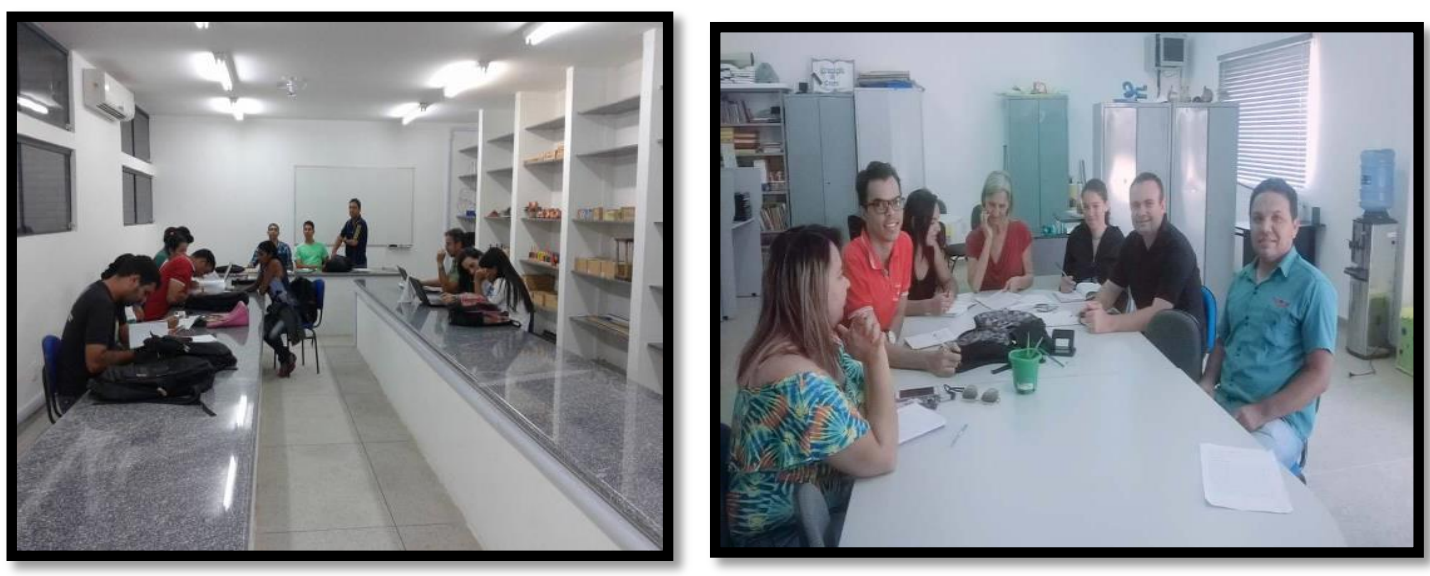

Fotos 17 e 18 - reuniões de planejamento coordenação de área e bolsistas.

\subsection{Atividades de integração com as escolas e a Universidade}

Durante todo o período o Programa também realizou uma série de estratégias que tiveram como finalidade socializar o trabalho realizado, envolver outras escolas e profissionais que não participavam diretamente do Pibid Diversidade. Dentre estas atividades podemos destacar:

a) Realização do Encontro de Iniciação a Docência do Pibid Diversidade, evento realizado anualmente, que envolvia todos os participantes do Programa, estudantes e professores/as do Curso, professores/as e estudantes das escolas públicas, também suscitou a participação de outras licenciaturas em Educação do Campo da região. A dinâmica do evento sempre possibilitou espaços de avaliação, socialização do trabalho realizado ao longo do ano, estudos e aprofundamentos de temáticas relacionadas à formação e a iniciação a docência. 


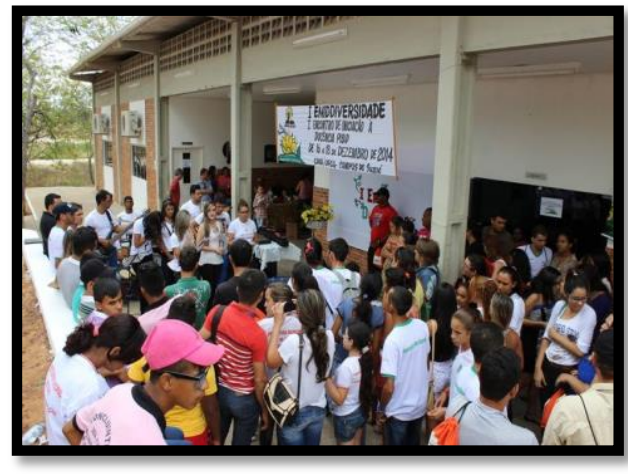

Foto 19 - I ENIDIVERSIDADE, 2015

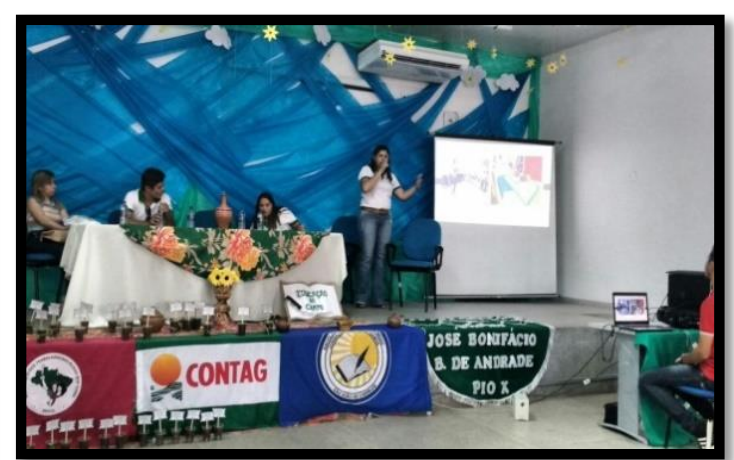

Foto 20 - II ENIDIVERSIDADE, 2016

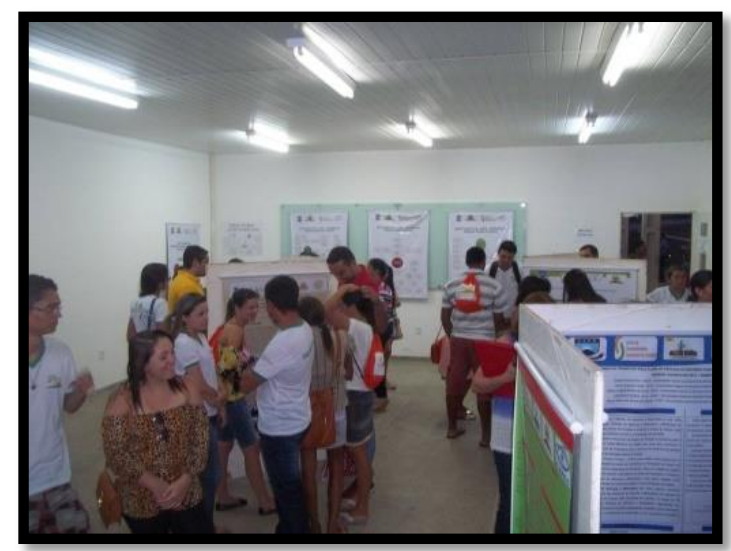

Foto 21- III ENIDIVERSIDADE, 2017

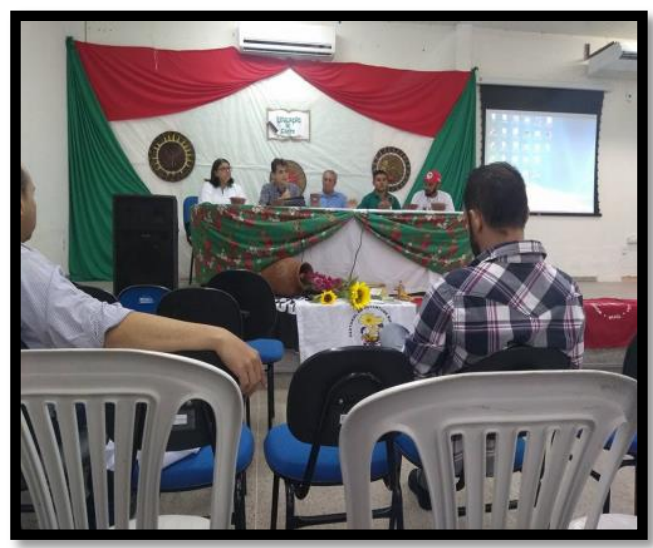

Foto 22 - IV ENIDIVERSIDADE, 2018.

b) Seminário Integrador da Licenciatura em Educação do Campo: Uma forma de envolvimento e integração de todos os estudantes do curso, que não são bolsistas, PIBID DIVERSIDADE foi a realização dos seminários integradores no inicio de cada ano letivo, na qual recepcionam os novos estudantes e realizam atividades formativas de discussão sobre a Educação do Campo, as áreas de conhecimento, a alternância, o estágio curricular supervisionado e outras temáticas pertinentes ao Projeto Pedagógico do Curso.
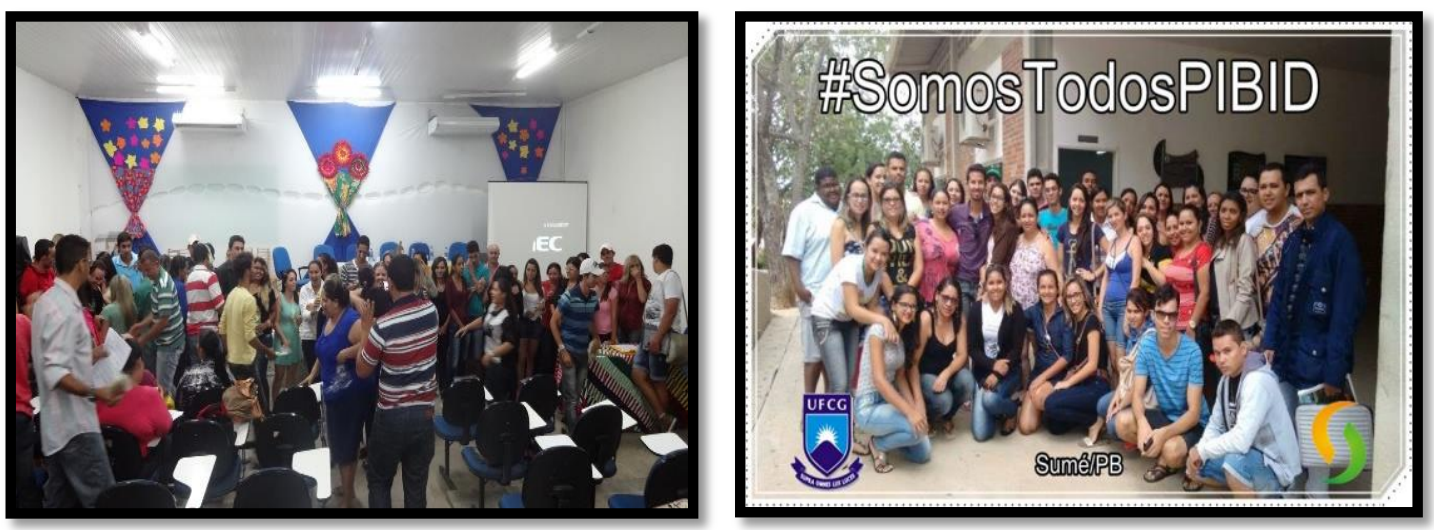

Fotos 23 e 24 : Seminário integrador do Curso 
c) Mostra Pedagógica das Escolas do Campo: ação desenvolvida pelo projeto que teve como finalidade articular e socializar o trabalho desenvolvido pelas escolas do campo do território. Esse momento possibilitava um intercambio entre as escolas, a visibilidade das ações que estavam sendo desenvolvidas na perspectiva da Educação do Campo e da contextualização.
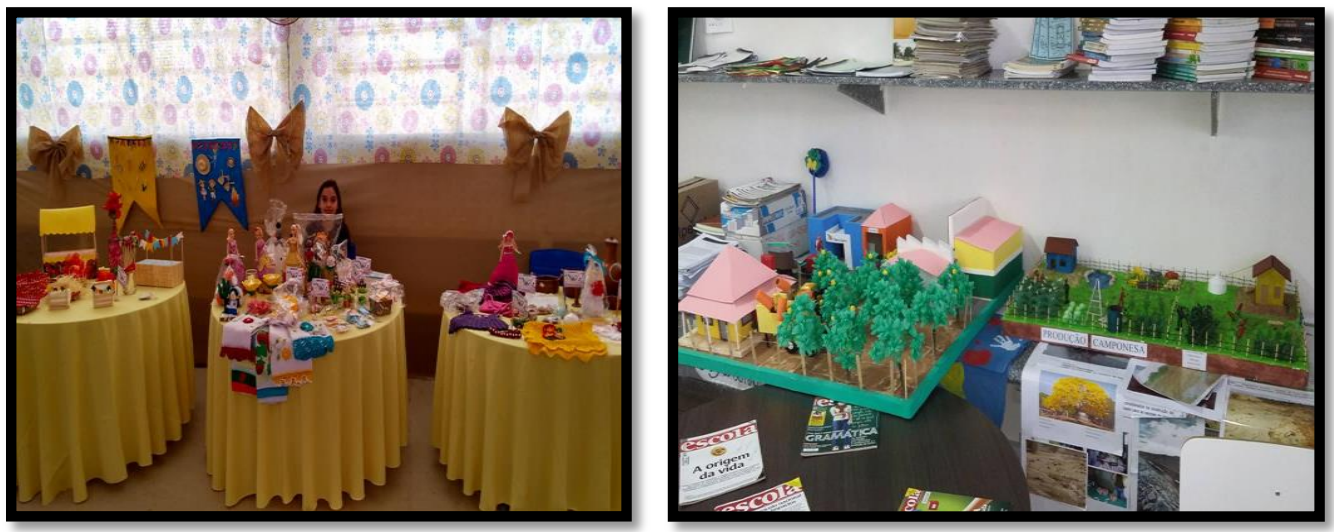

Fotos 25 e 26 - Produções de material das escolas

d) Atividades artístico-culturais: Este trabalho permitiu uma ampliação do trabalho do Projeto, envolvendo também as famílias e a comunidade interna e externa as escolas. Envolvia a produção realizada com as artes cênicas, visuais, educação musical e esporte desenvolvida pelo projeto e bolsistas.

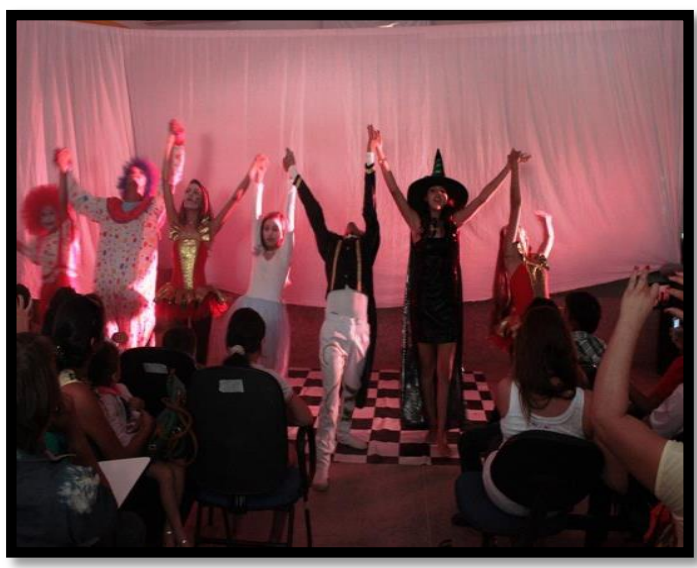

Foto 27 - Musical

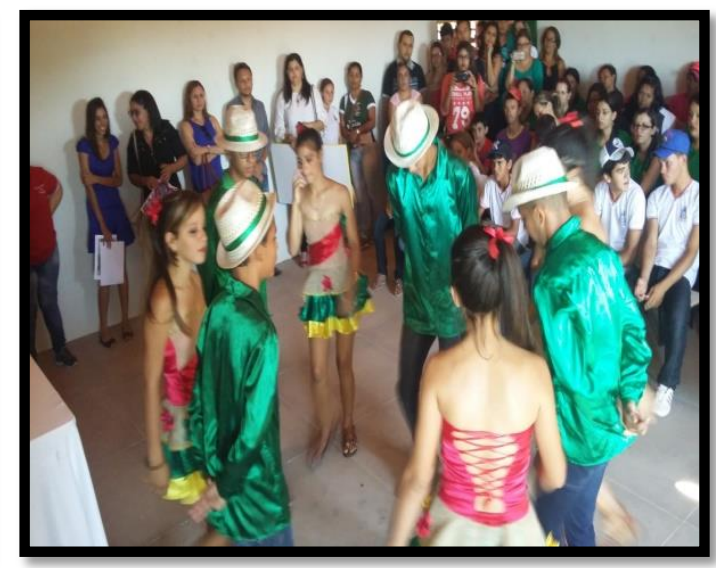

Foto 28 - Grupo de Dança 


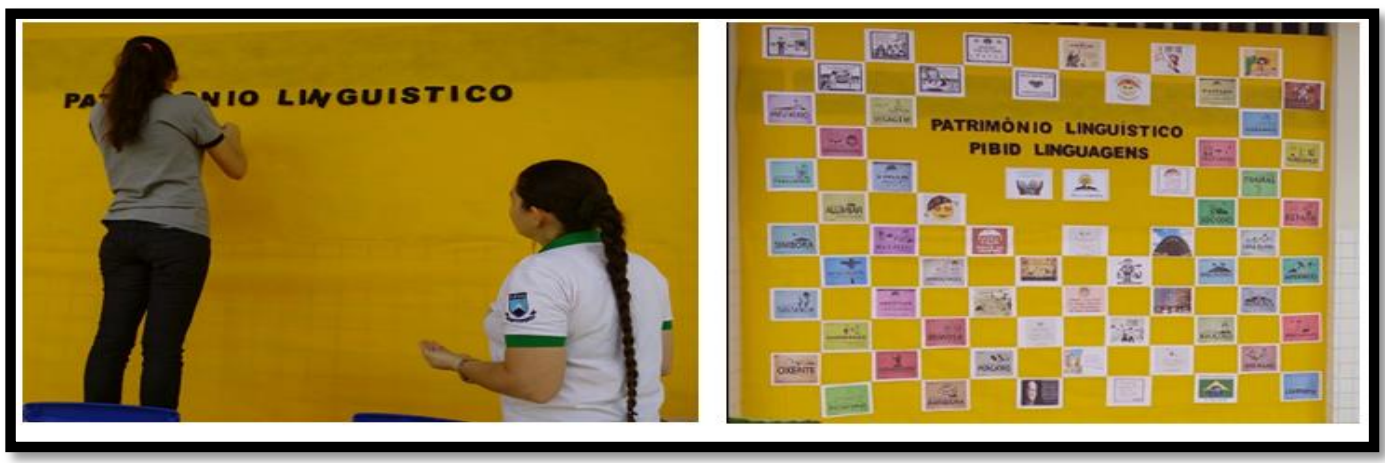

Foto 29 - Exposição Literária

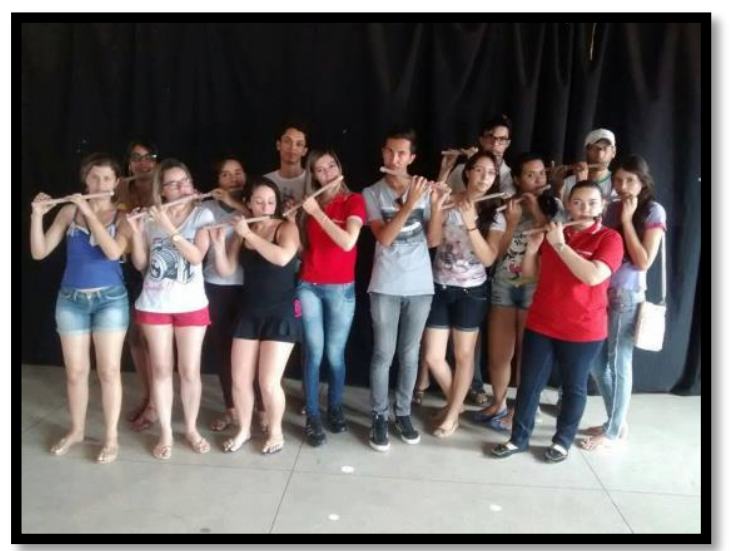

Foto 30 - Educação Musical

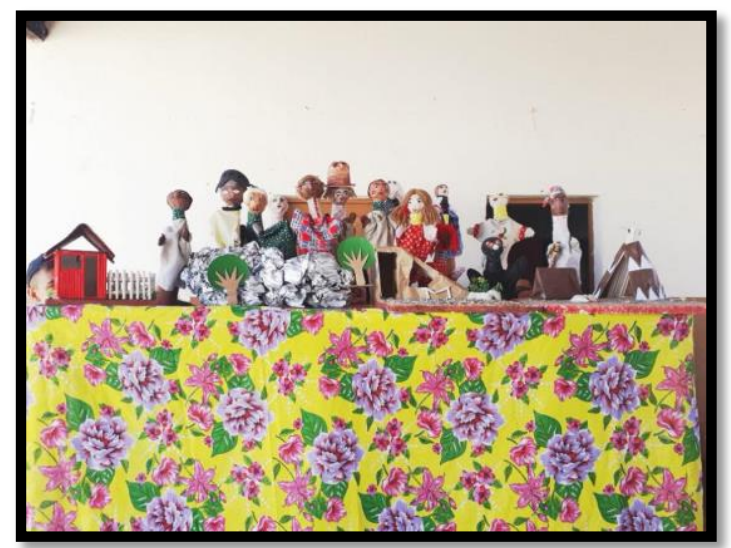

Foto 31 - Teatro de Fantoches

As oportunidades de estar no cotidiano escolar, de vivenciarem a escola em sua plenitude, desde os espaços de gestão, as práticas docentes, a relação entre professores/as, professores e alunos, equipe diretiva com os diferentes grupos que fazem parte da escola, até a presença ou ausência da família na escola, permitiram não somente uma aprendizagem diferenciada, Além disso, o constante diálogo e interação entre os membros dos subprojetos (licenciandos/as, coordenadores/as e supervisores/as) gera uma dinâmica única que possibilita um crescimento contínuo e formação recíproca.

\section{Análise e Resultados}

Durante todo o Programa realizamos diferentes procedimentos de avaliação do trabalho desenvolvido: reuniões com a equipe do projeto, reuniões nas escolas com a comunidade escolar, mesas avaliativas durante 0 Enidiversidade, etc. Ao final do projeto realizamos rodas de conversa para uma escuta dos participantes sobre qual percepção que possuíam da contribuição do Pibid Diversidade, sendo levantados os seguintes aspectos: formação dos estudantes/bolsistas, nas escolas de Educação Básica, na Licenciatura em Educação do Campo, na formação dos professores/as. 
6.1 Na formação dos estudantes/bolsistas

A aprendizagem do cotidiano do exercício docente e da organização da escola do campo apareceu de forma predominante nas falas, quando colocam "a oportunidade de conhecer o dia-a-dia dos/as professores/as e das escolas do campo". Além disto, Diferentes dimensões são destacadas pelos bolsistas como contribuições do Pibid Diversidade para sua formação, tais como: a relação com outros conhecimentos, com a prática em sala de aula, bem como a atuação interdisciplinar nos processos de ensinar e de aprender, pois,

O PIBID Diversidade permitiu o melhor entendimento sobre como trabalhar com a interdisciplinaridade em sala de aula, envolvendo além das disciplinas formais, os conhecimentos que envolvem as artes como teatro, música, dança, entre outras. A visão que pude obter da escola a partir do PIBID, além do que ser um espaço de promoção de conhecimento, é que é também de cultura, e através de projetos como esse beneficiamos os alunos com maiores especificações e formações para os iniciantes na docência. Isso contribui muito para nossas discussões em sala de aula com os colegas do curso, como também no nosso desempenho nas disciplinas do curso. (Bolsista do subprojeto de Linguagens e Códigos)

A partir da inserção no espaço escolar os bolsistas levam para as salas de aula das universidades as questões do cotidiano docente. Deste modo, entendemos que a compreensão do 'ser professor' se constrói ao longo do curso de Licenciatura, que vai se constituindo no enfrentamento dos desafios do cotidiano escolar e na vivência da complexidade que envolve o trabalho do professor possibilitado por esta articulação entre os espaços acadêmicos e a prática pedagógica nas escolas do campo.

O PIBID vem sendo de fundamental importância para minha vida acadêmica e profissional tendo em vista que, o PIBID proporciona aos bolsistas uma experiência rica dando embasamento teórico e prático para as experiências que permeiam o contexto escolar. Nessa perspectiva, o projeto também tem possibilitado a formação profissional através das produções científicas desenvolvidas no decorrer da trajetória acadêmica, tais como, publicações de artigos, resumos entre outros, participações em eventos e ainda às produções de cunho cultural como, por exemplo: apresentações teatrais e musicais. Sendo assim, as ações que foram desenvolvidas durante o projeto propiciou um novo olhar sobre a formação docente, ou seja, a revalorização e um novo conceito sobre o que é ser professor. (Bolsista do subprojeto ciências humanas e sociais). 
A dimensão da pesquisa e do aprofundamento do conhecimento cientifica, se modificou com a escrita e apresentações de trabalhos resultantes das práticas desenvolvidas nas escolas também foram ressaltadas como uma dimensão importante para sua formação profissional. Todos os bolsistas que participaram do debate consideraram que o Pibid Diversidade contribuiu para sua formação como professor/a-pesquisador/a, influenciando desde 0 aprendizado como organizar um pôster, uma comunicação oral, como apresentar trabalhos científicos até a escolha do objeto de pesquisa dos trabalhos de conclusão do curso.

\subsubsection{Nas Escolas da Educação Básica}

Uma primeira questão destacada pelas falas foi a maior integração entre escolas da educação básica e universidade com a participação dos professores em atividades formativas da universidade: seminários, palestras, cursos de especialização (estamos realizando dois cursos de especialização para 0 professorado da rede: especialização em Educação de jovens e Adultos para Economia Solidária e Formação de Professores em Ciências da Natureza e da Matemática. A Escola passa a ser vista como parceira, e não como objeto de pesquisa.

O olhar diferenciado do Programa para toda a comunidade escolar e os problemas que os cercam. Assim acontece na Escola Ildefonso Anselmo da Silva, convencia desde 2010, quando recebeu o Pibid e desde então as colaborações são visíveis para a melhoria da qualidade do processo de ensino e aprendizagem desta escola. Tudo inicia com os estudos realizados sobre a escola, identificando pontos positivos e negativos, e a partir de desta discursão, são elaborados plano de ações. Para realizações destas atividades, cria-se uma parceria com os professores para o desenvolvimento de atividades que contribui para a melhoria das dificuldades enfrentadas por este professor. Esse momento e muito valioso, onde bolsistas e professores fazem um diálogo e estudo sobre a situação problema, e disseminam um vasto conhecimento para ambos. (Supervisora da Escola Idelfonso Anselmo)

A inserção de novas metodologias de ensino, juntamente com produção de materiais ludo-pedagógicos e inserção de novos saberes curriculares, disciplinares e pedagógicos na educação básica, assim como 0 questionamento crítico sobre o conteúdo e sua relação com o cotidiano, buscando uma perspectiva educacional interdisciplinar, pois, 
O PIBID Diversidade, ao chegar à escola procura justamente conquistar a gestão escolar, coordenação e confiança dos professores e alunos ocasiona aos bolsistas adquirir uma experiência da vivência de sala de aula, assim como também colabora para a melhoria da educação e faz com que os professores da educação básica repensem sua prática e sintam parte integrante inseridos no projeto como colaboradores no processo de formação dos futuros docentes, uma vez que a escola é um espaço de formação. O PIBID oportuniza a união da prática e teoria conhecendo de perto a realidade da escola. As bolsistas buscam superar os problemas apresentados em sala de aula de uma forma interdisciplinar, motivando os alunos a novas descobertas e a novos meios de aprendizagem ainda não conhecidos (Coordenadora pedagógica da Escola José Bonifácio de Andrade).

Esta fala nos evidencia como o Pibid Diversidade também influenciou na gestão das escolas do campo, ao se deparar com demandas de espaços, tempos, sujeitos e saberes que se fortaleceram no cotidiano da organização do trabalho pedagógico e nas situações de ensino-aprendizagem.

A desconstrução da tensão inicial da chegada à escola também gera um processo de aprendizagem, do fazer docente. O conhecimento mútuo permite a construção de novas formas de convivência e o estabelecimento de relações mais igualitárias entre saberes, itinerário e papeis diferentes, no processo de ensino aprendizagem. Conforme nos mostra a fala abaixo:

Quando a gente começa, eu estava no segundo período do curso, porque na licenciatura, desde o inicio a gente tem contato com as comunidades, com as escolas, e o Pibid foi fundamental para ajudar nisto, porque na escola que eu fui nem todos os professores/as se envolveram logo no projeto, a maioria se manteve apático. Aos poucos a gente foi se aproximando e fazendo coisas juntos. A supervisora sempre estava ali ajudando a gente, conversando, planejando, tirando dúvidas... Então vai mudando (Bolsista de Ciências da Natureza e da Matemática)

A compreensão da formação como um processo recíproco, de troca, de relações, coadunando assim com o pensamento de Freire (1996, p. 23) quando assegura que "quem forma se forma e reforma ao formar e quem é formado forma-se e forma ao ser formado". A formação da educadora e do educador do campo precisa ser pautada num projeto político pedagógico voltado para a emancipação humana o que exige um conhecimento e diálogo com as práticas sociais que busquem soluções para as problemáticas das populações campesinas. 


\subsubsection{Na Licenciatura em Educação do Campo}

Esse estreitamento na interação entre essas duas instituições de ensino pode possibilitar uma melhoria na formação dos licenciandos/as, à medida que promove uma maior articulação entre a teoria e prática da docência,

O Pibid Diversidade traz uma grande contribuição para nossa licenciatura, porque possibilita uma vivencia com a docência numa perspectiva integrada de ensino, pesquisa, extensão. Porque estimula o dialogo com a Escola Pública do Campo na região. Notamos claramente em sala de aula a diferença no compromisso e no desempenho dos bolsistas que participam durante sua formação do Pibid. (Coordenador de Área do Pibid Diversidade)

De acordo com Caldart (2000, p. 50a) "olhar a escola como um lugar da formação humana significa dar-se conta de que todos os detalhes que compõem o seu dia a dia estão vinculadas a um projeto de ser humano, estão ajudando a humanizar ou desumanizar as pessoas". Portanto, a prática do Pibid Diversidade possibilitou um conhecimento não apenas dos estudantes, mais também dos docentes sobre a realidade das comunidades campesinas e das escolas do campo do território do cariri paraibano.

a) Formação dos professores/as

A contribuição do Pibid para a formação de professores/as foi destacada em diferentes dimensões Os apontamentos mais comuns foram relacionados à aprendizagem pela ludicidade, através de jogos e materiais didáticos mais dinâmicos, das propostas educacionais inovadoras que dialogam com 0 contexto no qual se inserem, bem, como o estímulo para a formação dos professores/as da Educação Básica em nível superior.

Foi o PIBID que despertou na gente a vontade de estudar, de pesquisar, de se engajar na defesa da escola publica. Para que possamos perceber que o professor tem que ser um pesquisador, e sua prática pedagógica é a principal referencia para sua reflexão e sua formação. Por isto, que como egressa do PIBID DIVERSIDADE, hoje continuo na Universidade fazendo agora minha pós- a especialização. A turma é composta por muitos egressos do PIBID, isto mostra o estimulo que o Programa gera em todos nós. (Egressa do Pibid Diversidade estudante da especialização) 
O trabalho colaborativo proporciona a solidariedade, a troca de experiências e de valores, saberes que não podem ser desenvolvidos individualmente, assim, estimula a formação continuada para 0 aprofundamento de seu papel como professor/a pesquisador/a. Isto dialoga com o conceito de "terceiro espaço na formação" proposto por Zeichner (2010, p. 486), pois,

Terceiros espaços envolvem uma rejeição das binaridades tais como entre 0 conhecimento prático profissional e 0 conhecimento acadêmico, entre a teoria e a prática, assim como envolve a integração, de novas maneiras, do que comumente é visto como discursos concorrentes - em que uma perspectiva do isso ou aquilo é transformada num ponto de vista do tanto isso, quanto aquilo.

No Pibid Diversidade essa articulação se estende para as comunidades campesinas nas quais as escolas estão situadas no sentido de romper com as formas hierárquicas de organização curricular e valorização cultural, articulando os conhecimentos práticos aos conhecimentos acadêmicos numa relação horizontal.

\subsection{A auto-organização dos/as educandos/as como base do processo pedagógico}

Os professores/as das escolas e os estudantes destacam a importância do Pibid Diversidade para as atividades na escola e na comunidade. No exercício coletivo de produção (hortas comunitárias, organização dos espaços de ensino, produção de material), no aprendizado sobre a cooperação (nas ações sóciopolíticas e organização comunitária) e na auto-organização dos estudantes (formação de equipes de trabalho nas escolas). Podemos perceber isto nos depoimentos e nas fotos.

O Pibid Diversidade não é somente um programa institucional que está preocupado apenas em colocar estudantes de licenciaturas dentro das escolas do país para formar professores. É um programa que também está preocupado com a melhora constante da educação, sobretudo, pública deste país. Os diálogos e os trabalhos realizados pelos bolsistas, pelos professores e pelas crianças e adolescentes na sala de aula sempre foram pensados para melhorar a escola, contextualizar o trabalho. Por isso, além de várias outras razões, é de extrema importância que seja dada continuidade ao Pibid, tanto para que a qualidade da formação dos futuros docentes não seja prejudicada, quanto para que, através 
dessas ações, nossa educação possa estar cada dia melhor. (bolsista Pibid Diversidade Ciências Humanas e Sociais).

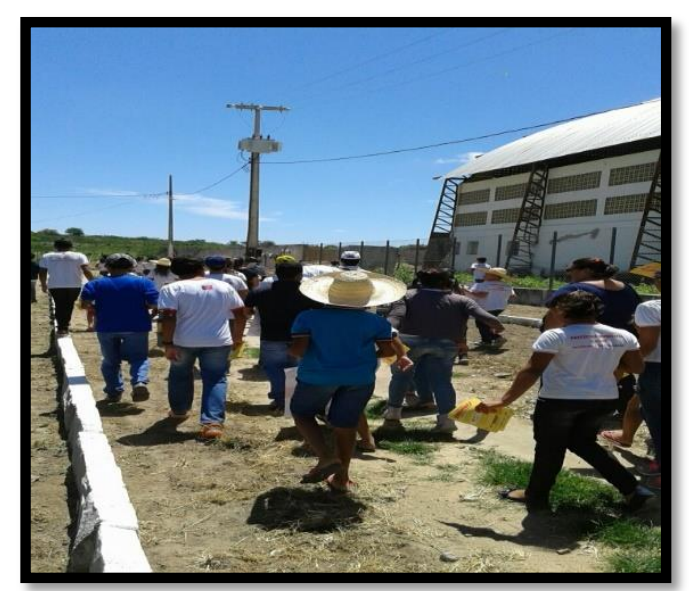

Foto 32 - Campanha contra a dengue

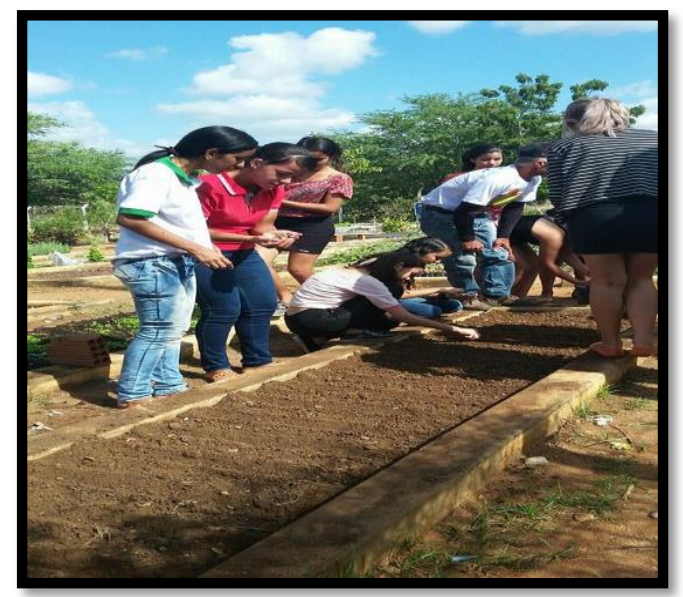

Foto 34 - Atividade produtiva na escola

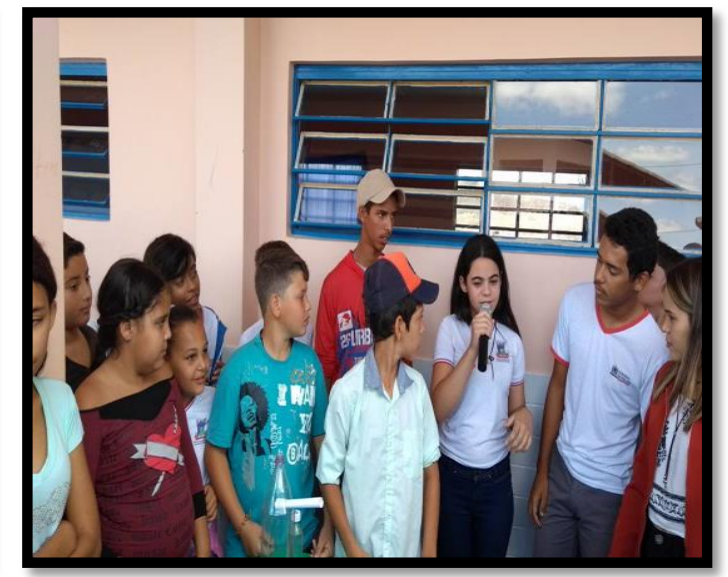

Foto 33 - Organização estudantil

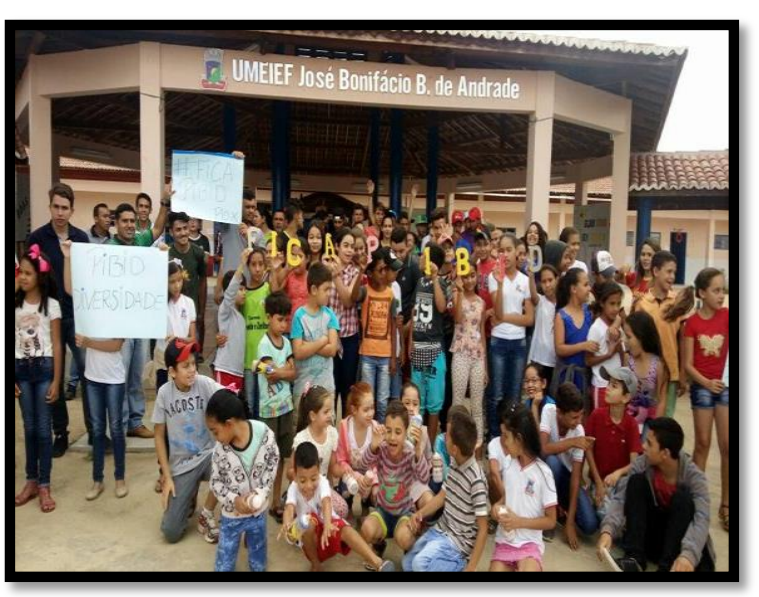

Foto 35 - Movimento Fica Pibid na Escola

A contribuição do Pibid Diversidade não se restringe somente às escolas parceiras, de acordo com Holanda e Silva (2013, p.9) o projeto contribui para a formação inicial dos bolsistas e para a formação continuada dos professores supervisores do projeto "mostrando-lhes posicionamentos diferenciados para alcançar correções para as deficiências atuais causadas por um ensino tradicional que impede os avanços para uma formação docente de qualidade".

A vivência de uma ação educativa num contexto bem mais amplo que a sala de aula, embora ela estivesse presente todo o tempo, possibilitou um contato com as tensões e contradições existentes nos território onde se localizam as escolas, e consequentemente a compreensão da totalidade dos processos envolvidos na relação ensino-aprendizagem, considero, portanto, esta uma das grandes contribuições do Pibid Diversidade para a Licenciatura em Educação do Campo. 


\section{Algumas Considerações}

O cenário educacional contemporâneo tem sido caracterizado por crescentes demandas de toda ordem social, cultural e econômica, marcada por reformas educacionais que sinalizam um retrocesso nas políticas de formação docente - inicial e continuada - que se pautam pela lógica dos organismos internacionais numa perspectiva gerencial da eficiência, eficácia e produtividade do processo de ensino-aprendizagem.

Assim, a lógica contra hegemônico presente no Movimento da Educação do Campo, ao lutar por todas as políticas educacionais, dentre elas o Pibid Diversidade, se fragilizam neste cenário de perdas de direitos e ameaças a democracia.

Ao retomar as ações desenvolvidas pelo Pibid Diversidade neste curto período de sua existência, percebemos avanços significativos para se pensar uma nova concepção de formação docente que se fundamente no diálogo entre teoria e prática, e na construção de conhecimentos, tempos, espaços e saberes distintos na Universidade, nas comunidades campesinas e nas escolas do campo. Processos estes que possibilitaram uma aproximação da Universidade e da Licenciatura das contradições reais que vivem os sujeitos do campo, as suas escolas e os profissionais que nela atuam.

Certamente, uma das grandes contribuições do Pibid Diversidade nesta relação entre universidade e escola, numa perspectiva de uma formação crítica, intercultural e contextualizada, possibilitou exercícios coletivos de elaboração do plano de trabalho a ser desenvolvido nas escolas, de compartilhamento de orientação realizada pelo professor/a supervisor/a e a coordenação de área, de troca de conhecimentos entre estudantes, professores/as e famílias.

Identificamos nas falas, nos registros, nas atividades desenvolvidas que quanto mais os subprojetos tinham uma interveniência planejada, sistemática, monitorada e compartilhada nestes dois espaços de formação, mais os sujeitos e seus produtos materializavam uma nova forma de pensarfazer a docência por área de conhecimento no campo.

A necessidade de ampliar e fortalecer esta estratégia de parceria entre Universidade e Escolas da Educação Básica, em toda a rede pública, e não apenas em algumas escolas (porque não conseguimos trabalhar com uma perspectiva de universalização nas escolas da rede), além de contribuir para que a formação docente se efetive a partir de problemáticas contextualizadas, no reforço a função social da educação escolar.

Esse estreitamento na interação entre essas duas instituições de ensino pode possibilitar uma melhoria na formação dos licenciandos/as, na perspectiva de construir práticas pedagógicas que superem a dicotomia teoriaprática numa perspectiva mais dialógica. 
Infelizmente, a partir de 2015, a continuidade do Pibid Diversidade, como política de Estado, passou a ser ameaçado, o que culminou em 2018 com sua desestruturação, e inclusão das licenciaturas interdisciplinar indígena e da Educação do Campo, num único Programa Pibid junto com as outras licenciaturas.

O movimento da Educação do Campo continua defendendo o Pibid Diversidade, como uma politica fundamental para a formação inicial, e neste sentido, a proposta atual da CAPES, cujo edital desconsidera as especificidades da Licenciatura em Educação do Campo, o que representa um retrocesso no trabalho desenvolvido, e um desafio para as propostas que ora se estruturam neste novo formato.

Este desafio se amplia pela fragilidade da articulação com os movimentos sociais, associações, sindicatos nas escolas do campo da região, bem como pela prática gestora centralizadora que permeia a maioria dos municípios da região.

\section{Referências}

ARROYO, Miguel. O direito a tempos-espaços de um justo e digno viver. In MOLL, Jaqueline et al. Caminhos da Educação Integral no Brasil: direito a outros tempos e espaços educativos. Porto Alegre: Penso, 2012, p. 33-45.

CALDART, Roseli. A escola do Campo em Movimento. In: BEJAMIN, César; Projeto Popular e Escolas do Campo. Brasília, DF: Articulação Nacional por Uma Educação do Campo, 2000. (Coleção Por Uma Educação do Campo, №. 03).

FREIRE, Paulo. Pedagogia da Autonomia: saberes necessários à prática educativa. São Paulo: Paz e Terra, 1996.

HOLANDA, D. S; SILVA, C. S. M. A contribuição do Pibid na formação docente: Um relato de experiência. Anais do XI Encontro Nacional de Educação Matemática ISSN 2178-034X. p 1- 13, 2013.

PPP - PROJETO POLÍTICO PEDAGÓGICO DA LICENCIATURA EM EDUCAÇÃO DO CAMPO-UFCG, 2009.

PIMENTA, S. G; LIMA, M.S.L. Estágio e docência: diferentes concepções. ed. Revista Poíesis -Volume 3, Números 3 e 4, p.5-24, 2006.

RELATÓRIO FINAL DE ATIVIDADES, PIBID-DIVERSIDADE DA UFCG, DEB/CAPES, 2018.

ZEICHNER, K. Repensando as conexões entre a formação na universidade e as experiências de campo na formação de professores em faculdades e universidades.

Educação. Santa Maria, v. 35, n. 3, p. 479-504, set./dez. 2010. 